\title{
PENGARUH PEMBERIAN ZINK (Zn) TERHADAP KUALITAS SPERMATOZOA WISTAR JANTAN DEWASA (Rattus norvegicus) YANG DIBERIKAN MONOSODIUM GLUTAMAT (MSG)
}

\author{
${ }^{1}$ Katarina K. Tandung \\ ${ }^{2}$ Lusiana Satiawati \\ ${ }^{2}$ Benny Wantow
}

\author{
${ }^{1}$ Kandidat Skripsi Fakultas Kedokteran Universitas Sam Ratulangi Manado \\ ${ }^{2}$ Bagian Biologi Fakultas Kedokteran Universitas Sam Ratulangi Manado \\ Email: kthandung_11_290@yahoo.com
}

\begin{abstract}
Zinc is a cofactor of more than 100 enzymes that are essential for the metabolism of nucleic acid and protein synthesis. Zinc plays an important role in growth and development, immune response, neurological and reproductive functions. Monosodium glutamate (MSG) is the sodium salt of glutamic acid , a food flavor enhancer in the form of L-glutamic acid. The purpose of this study was to determine the effect of zinc on sperm quality adult male wistar (Rattus norvegicus), following administration of monosodium glutamate (MSG). This study is experimental with a completely randomized design were conducted from November to Desember 2014 using a sample of 6 male wistars as a control group (P0) with 2 mg MSG being administered. The P1 group consist of 2 male wistars with $2 \mathrm{mg}$ of MSG and zinc at a dose of $10 \mathrm{mg}$ as treatment were administered to this group. The last group P2 also consist of 2 male wistars with the administration $2 \mathrm{mg}$ of MSG and $20 \mathrm{mg}$ doses of zinc as treatment.This study results in an increasement of spermatozoa consentration in the treatment group (P2), accounted for $78,25 \times 10^{6}$ as well as the increased of spermatozoa motility of 43,5 $\%$ for the treadment group (P2). Morfologically, 83,5 \% of normal spermatozoa were accounted from the same group. Conclusion: Administration of zinc can improve the quality of male wistar spermatozoa following the administration of MSG, which includes concentration, motility and morphology. The increasing dosage of zinc being administered showed higher impact in improving the quality of spermatozoa.
\end{abstract}

Keywords: zinc, MSG, male wistar, the quality of spermatozoa.

\begin{abstract}
Abstrak: Zink adalah kofaktor lebih dari 100 enzim yang penting untuk metabolisme asam nukleat dan sintesis protein. Zink berperan penting dalam pertumbuhan dan perkembangan, respon kekebalan, fungsi neurologis dan reproduksi. Monosodium glutamat (MSG) adalah garam natrium dari asam glutamat (glutamic acid), sebagai penambah rasa makanan dalam bentuk L-glutamic acid. Tujuan dari penelitian ini adalah untuk mengetahui pengaruh pemberian zink terhadap kualitas spermatozoa wistar jantan dewasa (Rattus norvegicus) yang telah diberi monosodium glutamat (MSG). Penelitian ini bersifat eksperimental dengan rancangan acak lengkap (completely randomized design) yang dilakukan pada bulan November sampai Desember 2014 dengan menggunakan sampel sebanyak 6 ekor terdiri dari 2 ekor wistar pemberian MSG dengan dosis $2 \mathrm{mg}$ sebagai kontrol $\left(\mathrm{P}_{0}\right)$, 2 wistar pemberian MSG dengan dosis $2 \mathrm{mg}$ dan zink dengan dosis $10 \mathrm{mg}$ sebagai perlakuan $\left(\mathrm{P}_{1}\right)$, dan 2 wistar pemberian MSG dengan dosis $2 \mathrm{mg}$ dan zink dengan dosis $20 \mathrm{mg}$ sebagai perlakuan $\left(\mathrm{P}_{2}\right)$. Hasil penelitian ini di dapatkan peningkatan konsentrasi spermatozoa pada kelompok perlakuan $\mathrm{P}_{2}$ sebesar $78,25 \times 10^{6}$, peningkatan motilitas spermatozoa kategori A pada perlakuan kelompok $\mathrm{P}_{2}$ sebesar 43,5\% dan morfologi normal spermatozoa pada kelompok perlakuan $\mathrm{P}_{2}$ sebesar $83,5 \%$. Simpulan: Pemberian zink dapat menyebabkan perbaikan pada
\end{abstract}


spermatozoa wistar jantan yang sebelumnya telah di beri MSG meliputi konsentrasi, motilitas, dan morfologi. Peningkatan dosis zink yang diberikan menunjukkan adanya perbaikan kualitas spermatozoa yang semakin meningkat juga.

Kata kunci: zink, MSG, wistar jantan, kualitas spermatozoa.

Zink adalah kofaktor lebih dari 100 enzim yang penting untuk metabolisme asam nukleat dan sintesis protein.Zink (Zn) disebut dengan seng merupakan zat gizi yang esensial. Metabolisme zink diangkut oleh albumin dalam plasma, disimpan dalam otot, tulang, dan organ.Zink ialah sebuah mikronutrisi yang biasa ditemukan di semua jaringan tubuh dan penting bagi pertumbuhan sel, diferensiasi sel dan sintesa DNA, juga penting untuk menjaga system daya tahan tubuh yang sehat. Mineral ini diperlukan untuk pertumbuhan, fungsi dan maturasi alat kelamin, nafsu makan dan ketajaman rasa, serta penyembuhan luka. ${ }^{1,2}$

Zink berperan penting dalam pertumbuhan dan perkembangan, respon kekebalan, fungsi neurologis dan reproduksi. Fungsi dan peran zink dalam tubuh antara lain membantu pembuatan materi genetic sel-sel, pembentukan sel darah merah (hemoglobin), serta membantu fungsi-fungsi pancreas dalam proses pencernaan. Zink banyak berperan dalam fungsi reproduksi yakni mineral zink berhubungan dengan stimulasi hormon androgen. Apabila mineral zink dalam darah tinggi maka stimulasi hormone androgen akan meningkat. Yang mana hormon androgen (testosteron) berfungsi dalam proses spermatogenesis. Zink yang merupakan konstituen dari peroksida dismutase, enzim yang melindungi sel-sel dari kerusakan yang disebabkan oleh radikalbebas.Zink menghasilkan system enzim yang membantu menetralkan radikal bebas. ${ }^{3,4}$

Monosodium glutamat (MSG) adalah garam natrium dari asam glutamat (glutamic acid). Monosodium glutamat telah dikonsumsi secara luas di seluruh dunia sebagai penambah rasa makanan dalam bentuk L-glutamic acid, karena penambahan MSG akan membuat rasa makanan menjadi lebih lezat. Masyarakat Indonesia rata-rata mengkonsumsi MSG sekitar $0,6 \mathrm{~g} / \mathrm{kg} \mathrm{BB}^{5}$

Monosodium glutamat (MSG) berupa bubuk kristal berwarna putih sejak lama telah digunakan sebagai bahan tambahan pada berbagai jenis makanan di berbagai negara. Kandungan garam natrium glutamate pada MSG berfungsi sebagai penguat dan penyedap rasa bila ditambahkan terutama pada makanan yang mengandung protein. ${ }^{6}$

Berdasarkan fungsi zink sebagai anti oksidan dan efek negatif dalam penggunaan monosodium glutamat (MSG) dosis tinggi, maka dari latar belakang di atas peneliti merasa tertarik untuk meneliti pengaruh pemberian zink terhadap kualitas spermatozoa wistar (Rattus norvegicus) jantan dewasa yang diberikan monozodium glutamat (MSG).

\section{METODE PENELITIAN}

Penelitian ini adalah penelitian eksperimental dengan rancangan acak lengkap (Completely randomized design). Penelitian dilakukan di Laboratorium Farmakologi Fakultas Kedokteran Universitas Sam Ratulangi Manado dengan rentang waktu sekitar Oktober-Desember 2014. Penelitian ini menggunakan sampel sebanyak 6 ekor wistar jantan yang dibagi menjadi 3 kelompok masing-masing kelompok terdiri dari 2ekor wistar jantan dan diberi perlakuan selama 52 hari dengan pemberian MSG dan zink melalui sonde lambung. Kelompok pertama merupakan kelompok kontrol yaitu kelompok yang diberi MSG dengan dosis $2 \mathrm{mg}$, kelompok kedua diberikan MSG dengan dosis $2 \mathrm{mg}$ dan zink dengan dosis $10 \mathrm{mg}$, kelompok ketiga diberikan MSG dengan dosis $2 \mathrm{mg}$ dan zink $20 \mathrm{mg}$. 


\section{HASIL PENELITIAN \\ Konsentrasi Spermatozoa}

Setelah dilakukan perlakuan pemberian MSG dan zink selama 52 hari dan penelitian terhadap kosentrasi spermatozoa wistar pada masing-masing kelompok maka didapatkan hasil seperti yang terlihat di tabel 1:

Tabel.1 Hasil Perhitungan Rata-Rata Konsentrasi Spermatozoa Wistar setelah Perlakuan Pemberian MSG dan Zink selama 52 hari.

\begin{tabular}{cc}
\hline Kelompok sampel & $\begin{array}{c}\text { Rata-rata konsentrasi } \\
\text { spermatozoa (x10 } \\
\text { ml.) }\end{array}$ \\
\hline per \\
\hline Kontrol $\left(\mathrm{P}_{0}\right)$ & 52,5 \\
Perlakuan $\left(\mathrm{P}_{1}\right)$ & 66,75 \\
Perlakuan $\left(\mathrm{P}_{2}\right)$ & 78,25 \\
\hline
\end{tabular}

Keterangan: Kelompok $\mathrm{P}_{0}$, kontrol (kelompok pemberian MSG dengan dosis $2 \mathrm{mg}$ ); Kelompok $\mathrm{P}_{1}$, kelompok pemberian MSG dengan dosis $2 \mathrm{mg}$ dan zink dengan dosis $10 \mathrm{mg}$; Kelompok $\mathrm{P}_{2}$, kelompok pemberian MSG dengan dosis $2 \mathrm{mg}$ dan zink $20 \mathrm{mg}$.

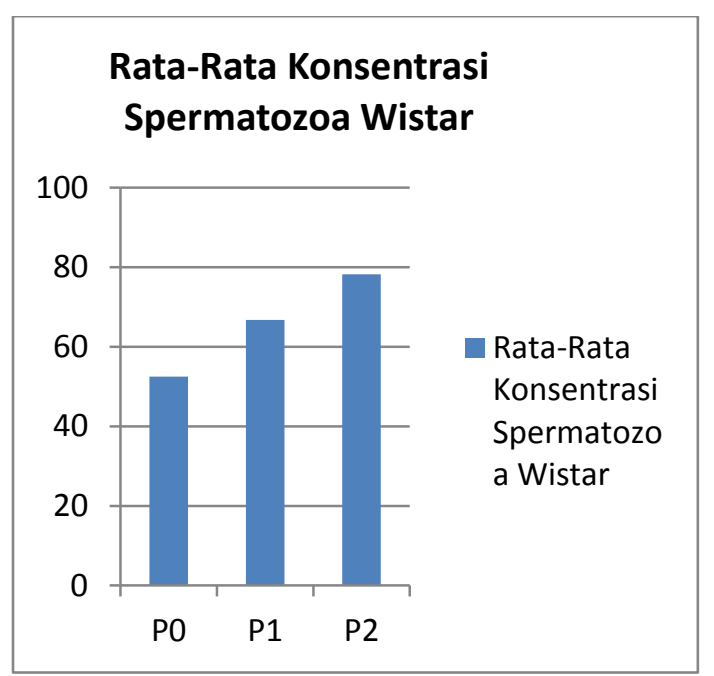

Gambar 1. Diagram Rata-Rata Konsentrasi Spermatozoa Wistar (Rattus Norvegicus) setelah Perlakuan dengan Pemberian MSG dan Zink selama 52 hari.

Berdasarkan Tabel 1 dan Gambar 1 dapat dilihat bahwa terdapat kecenderungan penurunan konsentrasi spermatozoa wistar pada kelompok $\mathrm{P}_{0}$ dengan pemberian MSG selama 26 hari, dan pada kelompok $\mathrm{P}_{1} \& \mathrm{P}_{2}$ cenderung mengalami peningkatan konsentrasi spermatozoa wistar setelah pemberian
MSG selama 26 hari dan dilanjutkan pemberian zink dengan dosis yang berbedabeda selama 26 hari berikut.

Kelompok $\mathrm{P}_{0}$ sebagai kelompok kontrol dengan pemberian MSG $2 \mathrm{mg}$ menunjukkan rata-rata konsentrasi spermatozoa yang mengalami penurunan sebesar 52,5 × $10^{6}$ sperma $/ \mathrm{ml}$ suspensi. Kelompok $\mathrm{P}_{1}$ sebagai kelompok perlakuan pemberian MSG dengan dosis sebesar $2 \mathrm{mg}$ dan zink dengan dosis sebesar $10 \mathrm{mg}$ menunjukkan rata-rata konsentrasi spermatozoa mengalami peningkatan sebesar 66,75x $10^{6}$ sperma/ml suspensi. Kelompok $\mathrm{P}_{2}$ sebagai kelompok perlakuan pemberian MSG dengan dosis sebesar $2 \mathrm{mg}$ dan zink dengan dosis sebesar $20 \mathrm{mg}$ menunjukkan rata-rata konsentrasi spermatozoa yang terus meningkat menjadi $78,25 \times 10^{6}$ sperma/ml suspensi atau lebih tinggi dibandingkan dengan kelompok perlakuan $\mathrm{P}_{1}$.

\section{Motilitas Spermatozoa}

Setelah dilakukan pemberian MSG dan zink selama 52 hari dan penilaian terhadap motilitas spermatozoa wistar pada masingmasing kelompok maka hasil didapatkan terbagi menjadi 3 kategori, yaitu kategori A sperma yang bergerak maju dengan cepat, kategori B sperma yang belok- belok sulit maju lurus atau lambat, kategori $\mathrm{C}$ sperma yang diam atau tidak bergerak.

\section{Motilitas Spermatozoa}

Motilitas spermatozoa kategori A adalah gerakan spermatozoa Wistar yang maju lurus dan cepat (progresif).

Tabel 2 Hasil Perhitungan Rata-Rata Motilitas Spermatozoa Wistar kategori A setelah Perlakuan Pemberian MSG dan Zink selama 52 hari.

\begin{tabular}{cc}
\hline $\begin{array}{c}\text { Kelompok } \\
\text { sampel }\end{array}$ & $\begin{array}{c}\text { Rata-Rata Motilitas } \\
\text { Kategori A (\%) }\end{array}$ \\
\hline Kontrol $\left(\mathrm{P}_{0}\right)$ & 0 \\
Perlakuan $\left(\mathrm{P}_{1}\right)$ & 35,5 \\
Perlakuan $\left(\mathrm{P}_{2}\right)$ & 43,5 \\
\hline
\end{tabular}

Keterangan: Kelompok $\mathrm{P}_{0}$, kontrol (kelompok pemberian MSG dengan dosis $2 \mathrm{mg}$ ); Kelompok $\mathrm{P}_{1}$, kelompok pemberian MSG dengan dosis $2 \mathrm{mg}$ dan zink dengan dosis $10 \mathrm{mg}$; Kelompok $\mathrm{P}_{2}$, kelompok pemberian MSG dengan dosis $2 \mathrm{mg}$ dan zink $20 \mathrm{mg}$. 
Tandung, Satiawati, Wantow: Pengaruh pemberian Zink...

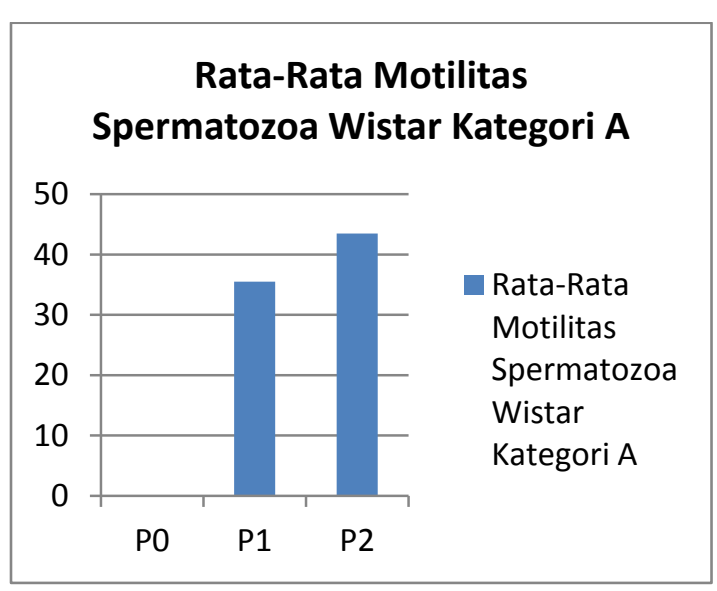

Gambar 2. Diagram Rata-Rata Motilitas Spermatozoa Wistar Kategori A (Rattus Norvegicus) setelah Perlakuan dengan Pemberian MSG dan Zink selama 52 hari.

Dari Tabel 2 dan Gambar 2 dapat dilihat bahwa terdapat kecenderungan penurunan presentase motilitas spermatozoa wistar kategori $\mathrm{A},\left(\mathrm{P}_{0}\right)$ setelah dilakukan perlakuan pemberian MSG selama 26 hari. Dan kecenderungan peningkatan persentase spermatozoa wistar $\left(\mathrm{P}_{1}\right)$ \& $\left(\mathrm{P}_{2}\right)$ setelah dilakukan perlakuan pemberian MSG 26 hari pertama kemudian dilanjutkan pemberian zink 26 hari selanjutnya.

Kelompok $\mathrm{P}_{0}$ yaitu kelompok kontrol dengan pemberian dosis MSG 2 mg menunjukkan rata-rata presentase motilitas spermatozoa yang menurun $0 \%$ Kelompok perlakuan $\mathrm{P}_{1}$ dengan pemberian dosis MSG $2 \mathrm{mg}$ dan zink $10 \mathrm{mg}$ menunjukkan ratarata presentase motilitas spermatozoa meningkat menjadi 35,5 \% sedangkan kelompok perlakuan $\mathrm{P}_{2}$ dengan pemberian dosis MSG $2 \mathrm{mg}$ dan zink $20 \mathrm{mg}$ menunjukkan rata-rata presentase motilitas spermatozoa wistar yang paling tinggi yaitu $43,5 \%$.

\section{Morfologi Spermatozoa}

Setelah dilakukan perlakuan pemberian MSG dan zink selama 52 hari dan penelitian terhadap morfologi spermatozoa wistar maka hasil yang didapatkan terbagi menjadi dua, yaitu morfologi normal dan abnormal spermatozoa wistar.

\section{Morfologi Normal Spermatozoa}

Tabel 3 Hasil Analisa Rata-Rata Morfologi Normal Spermatozoa Wistar Setelah Perlakuan Pemberian Zink selama 52 hari.

\begin{tabular}{cc}
\hline $\begin{array}{c}\text { Kelompok } \\
\text { sampel }\end{array}$ & $\begin{array}{c}\text { Rata-rata morfologi } \\
\text { normal } \\
\text { spermatozoa (100\%) }\end{array}$ \\
\hline Kontrol $\left(\mathrm{P}_{0}\right)$ & 27,75 \\
Perlakuan $\left(\mathrm{P}_{1}\right)$ & 78 \\
Perlakuan $\left(\mathrm{P}_{2}\right)$ & 73,25 \\
\hline
\end{tabular}

Keterangan: Kelompok $\mathrm{P}_{0}$, kontrol (kelompok pemberian MSG dengan dosis $2 \mathrm{mg}$ ); Kelompok $\mathrm{P}_{1}$, kelompok pemberian MSG dengan dosis $2 \mathrm{mg}$ dan zink dengan dosis $10 \mathrm{mg}$; Kelompok $\mathrm{P}_{2}$, kelompok pemberian MSG dengan dosis $2 \mathrm{mg}$ dan zink $20 \mathrm{mg}$.

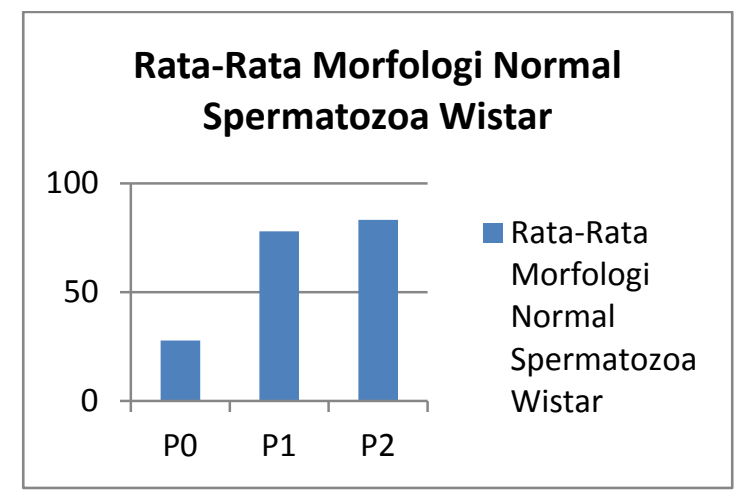

Gambar 3. Diagram Rata-Rata Morfologi Normal Spermatozoa Wistar (Rattus norvegicus) setelah Perlakuan dengan Pemberian MSG dan Zink selama 52 hari.

Dari Tabel 3 dan Gambar 3 dapat dilihat bahwa terdapat kecenderungan penurunan morfologi normal spermatozoa wistar pada kelompok $\mathrm{P}_{0}$ dengan pemberian MSG selama 26 hari, dan pada kelompok $\mathrm{P}_{1} \& \mathrm{P}_{2}$ cenderung mengalami peningkatan spermatozoa wistar setelah pemberian MSG selama 26 hari dan dilanjutkan pemberian zink dengan dosis yang berbedabeda selama 26 hari berikut.

Kelompok $\mathrm{P}_{0}$ yaitu kelompok kontrol dengan pemberian dosis MSG 2 mg menunjukkan rata-rata presentase morfologi normal spermatozoa yang menurun 27,25\% Kelompok perlakuan $\mathrm{P}_{1}$ dengan pemberian dosis MSG $2 \mathrm{mg}$ dan zink $10 \mathrm{mg}$ menunjukkan rata-rata 
presentase morfologi normal spermatozoa meningkat menjadi $78 \%$ sedangkan kelompok perlakuan $\mathrm{P}_{2}$ dengan pemberian dosis MSG $2 \mathrm{mg}$ dan zink $20 \mathrm{mg}$ menunjukkan rata-rata presentase motilitas spermatozoa wistar yang paling tinggi yaitu $83,25 \%$.

\section{BAHASAN}

\section{Konsentrasi Spermatozoa}

Pada penelitian ini didapatkan hasil analisis yang menunjukkan bahwa adanya peningkatan sejalan dengan bertambahnya dosis zink yang diberikan pada masingmasing kelompok perlakuan. Dari hasil analisis tersebut, semakin banyak dosis zink yang diberikan maka konsentrasi spermatozoa semakin meningkat. Peningkatan konsentrasi ini terjadi karena fungsi atau peranan mineral zink itu sendiri dalam fungsi reproduksi. Mineral zink berhubungan dengan stimulsi hormon androgen (testosteron) pada sel Leydig. ${ }^{7}$ Selain itu mineral zink berperan sebagai anti oksidan dan melindungi tubuh dari serangan lipid peroksidase dengan cara menghentikan reaksi radikal bebas pada oksidasi lipid. ${ }^{8}$

\section{Motilitas Spermatozoa}

Pada penelitian ini didapatkan hasil yang menunjukan bahwa semakin besar dosis zink yang diberikan maka motilitas spermatozoa meningkat karena sperma dapat menembus membran, bahkan konsentrasi yang kecil pun zink dapat dengan cepat menembus membran sperma dan mempengaruhi motilitas. ${ }^{9}$

\section{Morfologi Spermatozoa}

Pada penelitian ini peningkatan morfologi normal spermatozoa diakibatkan karena peran zink yang diketahui dapat menstimulasi hormon androgen sehingga dapat meningkatkan proses spermatogenesis yang normal. ${ }^{4}$

\section{SIMPULAN}

1. Pemberian MSG dapat menyebabkan penurunan kualitas spermatozoa secara nyata yang meliputi konsentrasi spermatozoa, motilitas spermatozoa, dan morfologi spermatozoa.

2. Pemberian Zink dapat menyebabkan perbaikan spermatozoa yang telah di beri MSG secara nyata yang meliputi konsentrasi spermatozoa, motilitas spermatozoa, dan morfologi spermatozoa.

3. Semakin besar dosis zink yang diberikan semakin besar efek peningkatan kualitas spermatozoa.

4. Zink dapat meningkatkan kualitas spermatozoa karena fungsi dan peranan zink dalam system reproduksi yaitu zink berfungsi sebagai antioksidan dan menstimulasi hormone androgen (testosteron) pada sel leyding sehingga dapat meningkatkan proses spermatogenesis yang normal.

\section{DAFTAR PUSTAKA}

1. Sulistia GG. Farmakologi dan terapi.edisi ke-5. Jakarta: Balai penerbit FKUI, 2009. p.791

2. Pertiwi CF. Pemberian xink dalam terapi diare pada anak. Farmakologi. 2004;67-71.

3. Kory PO. Pengaruh pemberian zink terhadap kualitas spermatozoa pada mencit jantan (Mus musculus). eBM. 2014;2:1-6.

4. Toelihere M. Inseminasi buatan pada ternak. Bandung: Angkasa,1993.

5. Riska RH, Edy SH, Poppy ZA. Pengaruh Pemberian Monosodium Glutamat (MSG) pada Pembentukan Mikronukleus Sel Darah Merah Mencit. Farmakologi. 2012;1:29-36.

6. Sukmaningsih ASGAA, EMA Gusti I, WI Nugrah, SW Ni. Gangguan Spermatogenesis Setelah Pemberian Monosodium Glutamat pada Mencit (Mus musculus L.) Biologi. 2011;XV(2):49-52.

7. Abbasi AAYS. Clarkson ang Gebner. Eksperimental Zink deficiency, effect on testicular fungtion. Clin Med. 1980;96:544-550.

8. Richard MP. Recent developments in trace element metabolism and function. Role of metallothionein in copper and zink metabolism. J.Nutr. 1989;199:1062-70. 
Tandung, Satiawati, Wantow: Pengaruh pemberian Zink...

9. Sorensen MB, Stoltenberg M, Danscher G, Ernst E. Chelation dari ion seng intraseluler mempengaruhi motilitas sel sperma manusia. Denmark. Molekuler Reproduksi Manusia. 1999;5(4):338-341. 